\title{
Effect of Celecoxib, a Cyclooxygenase-2-specific Inhibitor, has no Effect on Chronically Maintained Neuropathic Pain in Rats
}

\author{
Eun-Sung Park, Ph.D., Hyun-Jeong Kim, M.D., Min-Ju Lee, Ji-Yoon Lee, \\ Teo-Jeon Shin, M.D., Kwang-Suk Seo, M.D., and Kwang Won Yum, M.D. \\ Department of Dental Anesthesiology and Dental Research Institute, Seoul National University School of Dentistry, Seoul, Korea
}

Abstract

장기간 유지된 신경병증성 통증 흰쥐에서 선택적 COX2 억제제인 Celecoxib의 진통효과

\author{
서울대학교 치의학대학원 치과마취과학교실 \\ 박은성 · 김현정 · 이민주 · 이지윤 · 신터전 · 서광석 · 염광원
}

배경: 신경병증성 통증은 스테로이드, 아편유사제 등의 진통제에 잘 반응하지 않는다. 하지만 염증성 매개물질들이 신경병증성 통증의 발생에 관여한다는 보고가 있다. 특히 선택적 $\operatorname{COX} 2$ 억제 제인 celecoxib의 신경병증성 통증에 대한 효과에 관해서 상반된 연구결과가 존재한다. 본 연구는 신경병증성 통증 모델인 척추신경 결찰모델을 이용 기계적, 냉각 이질통 및 온도감각 과민현상의 발현에 celecoxib이 미치는 영향을 관찰하여 celecoxib의 항통각효과를 확인하고자 하였다.

방법: 30 마리의 쥐를 이용 척추신경을 결찰하여 신경병증성 통증을 유도하였다 celecoxib $(1,10$, 100 , and $300 \mathrm{mg} / \mathrm{kg}$ )을 경구 투여하였고 총 30마리 중 12마리의 쥐에서 열, 기계적자극에 대해서 통각과민, 냉각자극에 의해 이질통이 발생하였다. 약물 투여 후 $30,60,120,180$ 분 후 von Frey, 냉각자극검사, Hargreaves검사를 시행하여 쥐의 행동변화를 관찰하였다.

결과: 신경결찰 후 5 일 후에 celecoxib의 용량에 관계없이 열, 기계적 자극에 의한 통각과민, 냉각 자극에 대한 이질통을 감소시키지 않았다 $(\mathrm{P}>0.05)$. 또한 celecoxib투여에 의한 장기간의 항 통각 효과는 관찰되지 않았다 $(\mathrm{P}>0.05)$.

결론: celecoxib을 경구로 투여하였을 때 장기간 유지된 신경병증성 통증 흰쥐에서 약의 투여용 량, 투여기간에 따른 항 통각작용은 관찰되지 않았다. 따라서 조직 손상후 발생된 장기간의 신경병 증성 통증에 있어서 celecoxib은 효과가 없는 것으로 사료된다. (JKDSA 2008; 8: 29 34)

핵심용어: 이질통, Celecoxib, Cyclooxygenase-2, 통각과민, 척추신경결찰

\section{INTRODUCTION}

Neuropathic pain, characterized by spontaneous pain,

Corresponding author: Hyun Jeong Kim, Department of Dental Anesthesiology and Dental Research Institute, Seoul National University School of Dentistry 28 Yeongeon-dong Jongno-gu, Seoul 110-768, Korea Tel: +82-2-2072-3042, Fax: +82-2-766-9427

E-mail: dentane@snu.ac.kr hyperalgesia and allodynia, includes a multiplicity of causes (Jensen et al, 2001). To date, a lot of researches have been carried out to develop the useful animal models that can dependably give rise to a neuropathic pain-like syndrome in rodents and indicate an analgesic efficacy in human clinical approaches. For examples, chronic constriction injury (Bennett and Xie, 1988), partial sciatic nerve ligation (Seltzer et al, 1990), spinal nerve ligation (Kang et al, 2005), and lately the spared 
nerve injury (Bourquin et al, 2006; Decosterd and Woolf, 2000), have been developed.

Among diverse theories that describe the mechanisms of neuropathic pain, the close correlation between inflammatory responses and neuropathic pain states has been suggested (Bingham et al, 2005; Broom et al, 2004; Frisen et al, 1993; MacPherson, 2002; Tracey and Walker, 1995). Especially, local upregulation of cyclooxygenase 2 (COX2) at the lesion of peripheral nerve injury and the following release of prostaglandin E2 (PGE2) is closely related toperipheral sensitization, acting to change the threshold and excitability of the nociceptor peripheral terminal (McCleskey and Gold, 1999; O'Banion, 1999). On the other hand, COX2 mRNA expression is noticeably increased in the spinal cord after the injection of peripheral inflammatory stimuli such as complete Freund's adjuvant (CFA) (Hay et al, 1997) and carrageenan (Ichitani et al, 1997), which means that the increase of COX2 mRNA in the spinal cord is involved in inflammatory allodynia and hyperalgesia and implies that some of the analgesic effect of COX2 inhibitors are not peripheral but central (Hay et al, 1997; Samad et al, 2001; Tegeder et al, 2001; Yaksh et al, 2001; Yamamoto and Nozaki-Taguchi, 1997). Also, COX2 protein levels in the dorsal spinal cord and thalamus (but not in the ventral spinal cord, cingulate cortex and locus coeruleus) increased significantly one day after nerve ligation, compared with those in the sham animals (Zhao et al, 2000).

There have been lots of researches showing that COX2 plays a pivotal role in producing inflammatory pain. However, when it comes to in neuropathic pain models, the role of $\mathrm{COX} 2$ is still unclear because of various experimental settings. Therefore, the present study was carried out to evaluate the effectiveness of the selective COX2 inhibitor, celecoxib (Celebrex ${ }^{\circledR}$ ), on the long maintained neuropathic nociception evoked by spinal nerve ligation using behavioral tests including von Frey, cold, and Hargreaves' test, together.

\section{MATERIALS AND METHODS}

\section{Animals}

Thirty male Sprague-Dawley rats, 150-200 g (Central Lab. Animal Inc., Seoul, South Korea), were maintained in a climate-controlled room on a 12-h light/ dark cycle with lights on at $07: 00 \mathrm{~h}$ and food and water ad libitum. All procedures were performed in accordance with the guidelines specified in the NIH Guide for the Care and Use of Laboratory Animals (NIH publication No. 86-23, revised 1985) and the Ethical Guidelines for Investigations of Experimental Pain in Conscious Animals (Zimmermann, 1983). Every effort was conducted to minimize the number of animals used and their discomfort.

\section{Spinal Nerve Ligation (SNL) model of neuro- pathic pain}

The SNL model was performed as previously described (Kang et al, 2005) in 18 out of 30 rats showing no pain behaviors before surgery. Briefly, rats were anesthetized using isoflurane $(3 \%$ for induction followed by $2 \%$ for maintenance). After surgical preparation, the removal of the transverse process of left $6^{\text {th }}$ lumbar vertebra was made to uncover the $4^{\text {th }}$ and $5^{\text {th }}$ lumbar (L4 and L5) spinal nerves running just underneath the process. The L4 and L5 spinal nerves need to be separated in some animals to make the L5 spinal nerve accessible for ligation. Once enough length of the L5 spinal nerve is freed from the adjacent structure, a piece of 6-0 silk thread is placed around the L5 spinal nerve and the nerve is tightly ligated to interrupt all axons in the nerve. The incision was closed and rats were allowed to recover for at least 5 days.

\section{Behavioral testing and drug treatment}

All animals were allowed to adapt to the behavioral testing apparatus for at least three habituation sessions. Following habituation, at least two baseline measures were obtained for each of the behavioral tests in two 
separate sessions within the week before surgery. After completion of the surgical procedures, the behavioral tests were performed at appropriate intervals.

Mechanical allodynia: Rats were placed on a metal mesh grid covered by individual transparent plastic boxes $\left(8 \times 8 \times 18 \mathrm{~cm}^{3}\right)$. After $20 \mathrm{~min}$ acclimatization, a hindpaw withdrawal in response to normally innocuous mechanical stimuli was measured using von Frey monoflilaments $(0.2-15 \mathrm{~g})$. The base of the third and fourth toes was stimulated for threshold testing after the spinal nerve ligation. The mechanical threshold was determined by the up-down method (Dixon, 1980).

Cold allodynia: Rats were placed in individual plastic boxes with a mesh floor and allowed to explore and groom until they settled. A drop of acetone was applied to the plantar hindpaw using a feeding tube attached to a syringe without touching the skin. The duration of the withdrawal response was recorded with an arbitrary minimal value of $0.5 \mathrm{~s}$ and a maximum of $20 \mathrm{~s}$ (Choi et al, 1994).

Thermal hyperalgesia: Rats were placed in Perspex boxes and the lateral plantar surface was exposed to a beam of radiant heat through a transparent Perspex surface (Hugo Basile Inc., Italy) (Hargreaves et al, 1988). The withdrawal latency was measured with a minimal value of $0.5 \mathrm{~s}$ and a maximum of $20 \mathrm{~s}$. The heat stimulation was repeated 3 times at an interval of $5 \pm 10$ min for each paw and the mean calculated.

Drug treatment: At the 50th day after SNL operation, groups of three rats each received p.o. administration of either $1,10,100$, or $300 \mathrm{mg} / \mathrm{kg}$ of celecoxib $\left(\right.$ Celebrex ${ }^{\circledR}$, Pharmacia, South Korea) in 5\% carboxymethylcellulose sodium salt (CMC). After administration, von Frey, cold, and Hargreaves' tests were done at different time points $(30,60,120$, and 180 $\min )$.

\section{Statistics}

Animals were randomly assigned to each treatment group. Results are presented as mean \pm SEM. The data was analyzed using one-way ANOVA with post-

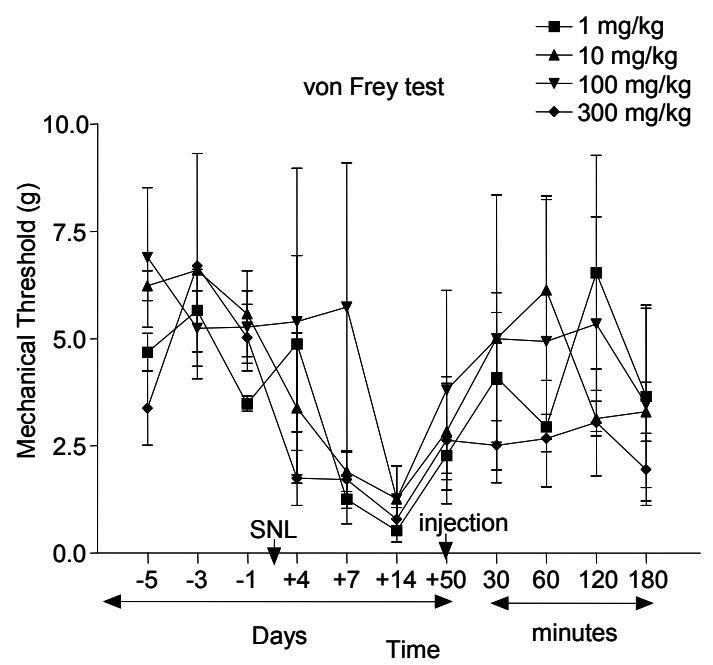

Fig. 1. The effect of celecoxib on mechanical allodynia 50 days after spinal nerve ligation. After establishment of baseline behavior, 1, 10, 100, and $300 \mathrm{mg} / \mathrm{kg}$ celecoxib were p.o. administered followed by mechanical allodynia testing was performed at different time courses (30, $60,120$, and $180 \mathrm{~min})$. There were no significant differences among groups $(\mathrm{P}>0.05)$. Data represent the mean \pm SEM.

hoc Bonferroni's multiple comparison methods (SPSS v. 10.0, SPSS Inc. Chicago, Illinois). The significance level was set at $\mathrm{P}<0.05$.

\section{RESULTS}

Two weeks after SNL, the threshold decreased significantly, which was consistent with the time course of the development of mechanical allodynia (Kang et al, 2005). At the 50th day after SNL, the definite maintenance phase of pain, the antinociceptive effect of oral celecoxib on mechanical allodynia was evaluated depending on drug dosages $(1,10,100$, and $300 \mathrm{mg} / \mathrm{kg}$ ) and time (30, 60, 120, and $180 \mathrm{~min})$ after the administration. All treated dosages of oral celecoxib failed to attenuate significantly the allodynic condition in response to application of von Frey filaments ( $P>0.05$, Fig. 1). Also, there was no significant difference in the effect of the drug at the 


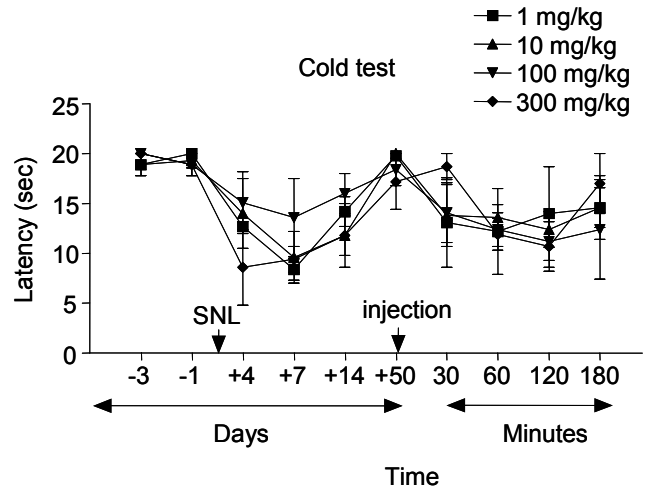

Fig. 2. The effect of celecoxib on cold allodynia 50 days after spinal nerve ligation. The withdrawal response duration (in seconds) after cold stimulation (acetone) was not significantly increased after celecoxib p.o. administration ( $\mathrm{P}$ $>0.05)$. Data represent the mean \pm SEM.

different time points $(\mathrm{P}>0.05$, Fig. 1). Furthermore, oral celecoxib also failed to show an antinociceptive effect on withdrawal latency following acetone application $(\mathrm{P}>0.05$, Fig. 2$)$ or radiant heat exposure $(\mathrm{P}$ $>0.05$, Fig. 3).

\section{DISCUSSION}

Neuropathic pain, which is difficult to treat with conventional analgesics such as NSAIDs and opioids, has continued to be challenge for clinicians and preclinical researchers so far. In addition, the mechanisms associated with neuropathic pain are still not clear. Unfortunately, alternative medications have not proven definitely effective. On the other hand, the role of spinal COX in nociception has been implicated in several studies (Uda et al, 1990; Yaksh and Malmberg, 1993). COX is the key enzyme in the synthesis of prostaglandins (PGs) from arachidonic acids. COX has two isoforms, COX1 and COX2. COX1, the constitutive isoform, is expressed in most tissues and thought to mediate physiological actions (Dubois et al, 1998; Feng et al, 1993). However, the prominent inducibility of $\mathrm{COX} 2$ in neurons by synaptic stimuli

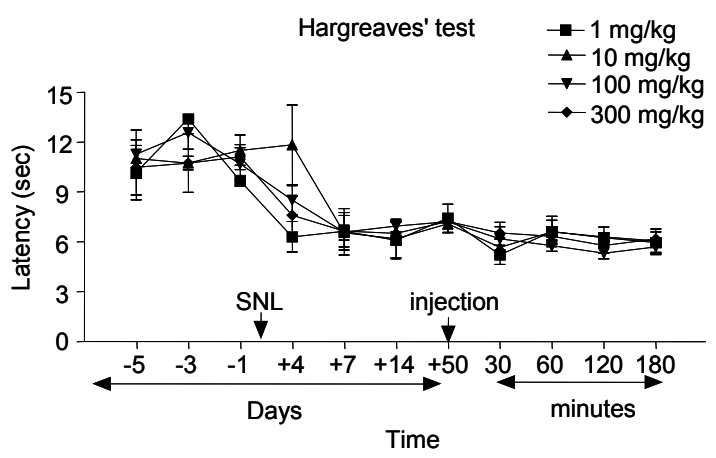

Fig. 3. The effect of celecoxib on thermal hyperalgesia 50 days after spinal nerve ligation. In all groups, the withdrawal response latency (in seconds) to nociceptive heat stimulation (Hargreaves' test) was not significantly increased after celecoxib p.o. administration $(\mathrm{P}>0.05)$. Data represent the mean \pm SEM.

suggests that it may play a important role in the development of neuroplasticity associated with neuropathic pain (Yamagata et al, 1993).

In the present study, SNL model was used for neuropathic pain-like behavior and celecoxib, one of NSAIDs, was orally administered with different dosages $1,10,100$, and $300 \mathrm{mg} / \mathrm{kg}$ at the 50 th day after SNL nerve injury for dealing with chronically maintained neuropathic pain-like behavior. Celecoxib, a selective COX2 inhibitor, failed to relieve allodynia and hypersensitivity in SNL model of neuropathic pain, which suggests that at least $\mathrm{COX} 2$ may not be involved in the maintenance of allodynia and hypersensitivity caused by SNL. Although the drug or neuropathic pain model or drug administration route of our study is different from ones of several previous studies, our behavioral results are somewhat consistent with ones of them. For example, first, intrathecal injection of $100 \mu \mathrm{g}$ of indomethacin immediately or one day after nerve ligation attenuated the development of tactile allodynia but had no effect on established allodynia 14 days after ligation (Zhao et al, 2000). Zhao et al. (Zhao et al, 2000), also, studied that COX2 protein levels in the dorsal spinal cord and thalamus increased 
significantly one and 14 days after nerve ligation, compared with those in the sham rats. Therefore, Zhao et al. suggested that spinal COX2 probably plays a critical role in the early development, but not in the maintenance, of tactile allodynia caused by the nerve injury in SNL model of neuropathic pain. On the basis of Zhao et al.'s results, we can, also, implicate when celecoxib is applied long period after nerve injury, it has no effect in lessening allodynia and hyperalgesia produced by SNL despite the very high dose administration of celecoxib. Secondly, recently, it was suggested that rofecoxib treatment (1 and 3.2 $\mathrm{mg} / \mathrm{kg}$ i.p. for 5 and 3 days respectively starting on the day of SNI surgery) failed to modify the initiation of allodynia and hyperalgesia in the SNI model (Broom et al, 2004) However, Broom et al. found that rofecoxib significantly reduced inflammatory hypersensitivity evoked by injection of CFA into one hindpaw (Broom et al, 2004). Therefore, Broom et al. suggested that COX2 is not related to dorsal horn neurotransmission after SNI and is not important for any central sensitization that may occur in SNI model. Furthermore, they insisted that COX2 does not appear to be involved either in the development or long term maintenance of allodynia and hyperalgesia following SNI because rofecoxib, the selective COX2 inhibitor, failed to ameliorate neuropathic pain-like behaviors in SNI model (Broom et al, 2004).

In summary, even though the drug or neuropathic pain model used in studies was different each other, it is still controversial whether COX2 is important or involved in neuropathic pain or not. However, we can conclude that celecoxib has no the antinociceptive effect, at least, on chronically long-term sustained thermal hyperalgesia, and mechanical as well as thermal allodynia caused by SNL in rats. Therefore, it may be thought that it is not satisfactory to treat the long-term established neuropathic pain with celecoxib.

\section{REFERENCES}

Bennett GJ, Xie YK: A peripheral mononeuropathy in rat that produces disorders of pain sensation like those seen in man. Pain 1988; 33: 87-107.

Bingham S, Beswick PJ, Bountra C, Brown T, Campbell IB, Chessell IP, et al: The cyclooxygenase-2 inhibitor GW406381X [2-(4-ethoxyphenyl)-3-[4-(methylsulfonyl) phenyl]-pyrazolo[1,5-b]pyridazine] is effective in animal models of neuropathic pain and central sensitization. J Pharmacol Exp Ther 2005; 312: 1161-9.

Bourquin AF, Suveges M, Pertin M, Gilliard N, Sardy S, Davison AC, et al: Assessment and analysis of mechanical allodynia-like behavior induced by spared nerve injury (SNI) in the mouse. Pain 2006; 122: 14 e1-14.

Broom DC, Samad TA, Kohno T, Tegeder I, Geisslinger G, Woolf CJ: Cyclooxygenase 2 expression in the spared nerve injury model of neuropathic pain. Neuroscience 2004; 124: 891-900.

Choi Y, Yoon YW, Na HS, Kim SH, Chung JM: Behavioral signs of ongoing pain and cold allodynia in a rat model of neuropathic pain. Pain 1994; 59: 369-76.

Decosterd I, Woolf CJ: Spared nerve injury: an animal model of persistent peripheral neuropathic pain. Pain 2000; 87: 149-58.

Dixon WJ: Efficient analysis of experimental observations. Annu Rev Pharmacol Toxicol 1980; 20: 441-62.

Dubois RN, Abramson SB, Crofford L, Gupta RA, Simon LS, Van De Putte LB, et al: Cyclooxygenase in biology and disease. Faseb J 1998; 12: 1063-73.

Feng L, Sun W, Xia Y, Tang WW, Chanmugam P, Soyoola E, et al: Cloning two isoforms of rat cyclooxygenase: differential regulation of their expression. Arch Biochem Biophys 1993; 307: 361-8.

Frisen J, Risling M, Fried K: Distribution and axonal relations of macrophages in a neuroma. Neuroscience 1993; 55: 1003-13.

Hargreaves K, Dubner R, Brown F, Flores C, Joris J: A new and sensitive method for measuring thermal nociception in cutaneous hyperalgesia. Pain 1988; 32: 7788.

Hay $\mathrm{CH}$, Trevethick MA, Wheeldon A, Bowers JS, de Belleroche JS: The potential role of spinal cord cyclooxygenase- 2 in the development of Freund's completeadjuvant-induced changes in hyperalgesia and allodynia. Neuroscience 1997; 78: 843-50.

Ichitani Y, Shi T, Haeggstrom JZ, Samuelsson B, Hokfelt T: Increased levels of cyclooxygenase-2 mRNA in the rat spinal cord after peripheral inflammation: an in situ hybridization study. Neuroreport 1997; 8: 2949-52. 
Jensen TS, Gottrup H, Sindrup SH, Bach FW: The clinical picture of neuropathic pain. Eur J Pharmacol 2001; 429: 1-11.

Kang WS, Park JS, Kim JW, Yoon SM, Park JY: Effects of Cyclooxygenase Inhibitors on Neuropathic Pain following Spinal Nerve Ligation in Rats. Korean J Anesthesiol 2005; 49: S41-S46.

MacPherson RD: New directions in pain management. Drugs Today (Barc) 2002; 38: 135-45.

McCleskey EW, Gold MS: Ion channels of nociception. Annu Rev Physiol 1999; 61: 835-56.

O'Banion MK: Cyclooxygenase-2: molecular biology, pharmacology, and neurobiology. Crit Rev Neurobiol 1999; 13: 45-82.

Samad TA, Moore KA, Sapirstein A, Billet S, Allchorne A, Poole S, et al: Interleukin-1beta-mediated induction of Cox-2 in the CNS contributes to inflammatory pain hypersensitivity. Nature 2001; 410: 471-5.

Seltzer Z, Dubner R, Shir Y: A novel behavioral model of neuropathic pain disorders produced in rats by partial sciatic nerve injury. Pain 1990; 43: 205-18.

Tegeder I, Niederberger E, Vetter G, Brautigam L, Geisslinger G: Effects of selective COX-1 and -2 inhibition on formalin-evoked nociceptive behaviour and prostaglandin $\mathrm{E}(2)$ release in the spinal cord. $\mathrm{J}$ Neurochem 2001; 79: 777-86.

Tracey DJ, Walker JS: Pain due to nerve damage: are inflammatory mediators involved? Inflamm Res 1995; 44: $407-11$

Uda R, Horiguchi $\mathrm{S}$, Ito $\mathrm{S}$, Hyodo $\mathrm{M}$, Hayaishi $\mathrm{O}$ :
Nociceptive effects induced by intrathecal administration of prostaglandin D2, E2, or F2 alpha to conscious mice. Brain Res 1990; 510: 26-32.

Yaksh TL, Malmberg AB: Spinal actions of NSAIDS in blocking spinally mediated hyperalgesia: the role of cyclooxygenase products. Agents Actions Suppl 1993; 41: 89-100.

Yaksh TL, Dirig DM, Conway CM, Svensson C, Luo $\mathrm{ZD}$, Isakson PC: The acute antihyperalgesic action of nonsteroidal, anti-inflammatory drugs and release of spinal prostaglandin E2 is mediated by the inhibition of constitutive spinal cyclooxygenase-2 (COX-2) but not COX-1. J Neurosci 2001; 21: 5847-53.

Yamagata K, Andreasson KI, Kaufmann WE, Barnes CA, Worley PF: Expression of a mitogen-inducible cyclooxygenase in brain neurons: regulation by synaptic activity and glucocorticoids. Neuron 1993; 11: 371-86.

Yamamoto T, Nozaki-Taguchi N: Role of spinal cyclooxygenase (COX)-2 on thermal hyperalgesia evoked by carageenan injection in the rat. Neuroreport 1997; 8: 2179-82.

Zhao Z, Chen SR, Eisenach JC, Busija DW, Pan HL: Spinal cyclooxygenase-2 is involved in development of allodynia after nerve injury in rats. Neuroscience 2000; 97: 743-8.

Zimmermann M: Ethical guidelines for investigations of experimental pain in conscious animals. Pain 1983; 16: $109-10$. 